\title{
PENGARUH PENGAWASAN KEUANGAN, PEMANFAATAN TI, KOMITMEN ORGANISASI, DAN KOMPETENSI SDM TERHADAP KETERANDALAN PELAPORAN KEUANGAN PEMERINTAH DAERAH KABUPATEN JEMBER
}

\author{
Lelly Rahayu ${ }^{1 *}$, Dessy Putri Andini ${ }^{1}$ \\ ${ }^{1}$ Politeknik Negeri Jember, Jl. Mastrip PO BOX 164 Jember, Indonesia \\ *Korespondensi: lellyrahayu0@gmail.com
}

\begin{abstract}
This study aims to determine the Effect of Financial Supervision, Utilization of IT, Organizational Commitment, and Competency of Human Resources on the Reliability of Financial Reporting for the Regional Government of Jember Regency. The study used a descriptive method with a quantitative approach, which was carried out by distributing research questionnaires to 100 employees of SKPD financial management in Jember Regency. The data analysis technique in this study used Structural Equation Modeling based on Partial Least Square (PLS-SEM). The results of this study are financial supervision, and organizational commitment have a significant positive effect on the reliability of the financial reporting of the Jember Regency Government. Meanwhile, the use of information technology (IT) and human resource competence has no effect.

Keywords: Reliability of reporting, HR competence

ABSTRAK

Penelitian ini bertujuan untuk mengetahui Pengaruh Pengawasan Keuangan, Pemanfaatan TI, Komitmen Organisasi, Dan Kompetensi SDM Terhadap Keterandalan Peleporan Keuangan Pemerintah Daerah Kabupaten Jember. Penelitian menggunakan metode deskriptif dengan pendekatan kuantitatif, yang dilakukan dengan membagikan kuesioner penelitian ke 100 orang pegawai pengelola keuangan SKPD di Kabupaten Jember. Teknik analisis data dalam penelitian ini menggunakan Structural Equation Modeling berbasis Partial Least Square (PLS-SEM). Hasil dari penelitian ini adalah pengawasan keuangan, dan komitmen organisasi berpengaruh positif signifikan terhadap keterandalan pelaporan keuangan Pemerintah daerah Kabupaten Jember. Sedangkan pemanfaatan teknologi informasi (TI) dan kompetensi SDM tidak berpengaruh.
\end{abstract}

Kata kunci: Keterandalan Pelaporan, Kompetensi SDM 


\section{PENDAHULUAN}

Pelaporan keuangan pemerintah di Indonesia menjadi topik bahasan yang selalu menarik untuk dikaji, dengan tuntutan atas akuntabilitas lembaga publik yang semakin besar baik di lembaga publik pusat maupun daerah. Dalam rangka menegakkan tanggung jawab terhadap akuntabilitas khususnya pada kinerja finansial, pemerintah daerah diharuskan bersikap transparan dengan cara mempublikasikan laporan keuangannya kepada pemangku kepentingan. Oleh karena itu, keterandalan saat pelaporan keuangan merupakan syarat penting yang harus dipenuhi. Berdasarkan PP No 71 Tahun 2010 Tentang Standar Akuntansi Pemerintahan, menyebutkan bahwa laporan keuangan yang baik syaratnya yaitu;

1. Andal, yang berarti bahwa informasi yang dilampirkan dalam laporan keuangan telah sesuai dengan fakta yang terjadi secara jelas, dan jujur serta bebas dari kesalahan material.

2. Relevan, jika informasi yang dilampirkan pada laporan keuangan harus bisa memberikan umpan balik atau dapat memengaruhi kebijakan yang diambil pengguna, membantu pihak pengguna untuk dapat memprediksi hasil yang akan didapat melalui peristiwa masa lalu dan sekarang.

3. Dapat dibandingkan, informasi yang terlampir pada laporan keuangan harus dapat dibandingkan dengan laporan keuangan periode sebelumnya dan laporan keuangan entitas lain, untuk dapat dilakukan evaluasi.

4. Dapat dipahami, informasi yang terlampir pada laporan keuangan harus mudah dipahami oleh pemangku kepentingan.

Pengawasan keuangan bertujuan untuk memastikan agar anggaran yang telah diatur benar-benar terlaksana, memastikan pelaksanaan APBD sesuai dengan anggaran yang telah diatur dan dapat dipertanggungjawabkan, serta meminimalisir terjadinya salah saji material yang disebabkan kelalaian dalam proses penyusunan laporan keuangan. Menurut (Susanto, 2017), suatu informasi yang berkualitas harus memiliki ciri-ciri:

1. Akurat artinya informasi harus mencerminkan keadan yang sebenarnya. Pengujian akurasi dilakukan oleh dua orang atau yang lebih berbeda, apabila pengujian pengujian tersebut menghasilkan hasil yang sama maka data tersebut dianggap akurat.

2. Tepat waktu artinya informasi itu harus tersedia atau ada pada saat informasi tersebut diperlukan, tidak besok atau tidak beberapa jam lagi.

3. Relevan artinya informasi yang diberikan harus sesuai dengan yang dibutuhkan oleh individu yang ada di berbagai tingkatan dan bagian dalam organisas.

4. Lengkap artinya informasi harus diberikan secara lengkap. Misalnya informasi tentang penjualan tidak ada bulannya atau tidak ada data fakturnya.

Perkembangan teknologi yang pesat serta potensi pemanfaatan yang begitu luas dan tidak terbatas juga dapat menjadi kesempatan bagi banyak pihak untuk dapat mengakses, mengelola dan mendayagunakan informasi secara cepat dan akurat. Sehingga dapat mewujudkan kualitas pemerintahan yang bersih dan transparan. Dalam upaya untuk mendapatkan kualitas informasi laporan keuangan yang baik diperlukan ketersediaan sumber daya manusia yang berkualitas pula. Pegawai yang dapat lebih lama bertahan dalam organisasi adalah yang memiliki komitmen besar terhadap organisasinya dibandingkan dengan pegawai yang rendah komitmen pada organisasinya. 
Berdasarkan opini yang dikeluarkan oleh Badan Pemeriksa Keuangan Republik Indonesia (BPK) pada Laporan Keuangan Pemerintah Daerah (LKPD) Kabupaten Jember tahun anggaran 2016 hingga tahun anggaran 2019. di tahun anggaran 2016 LKPD Kabupaten Jember memperoleh opini Wajar Dengan Pengecualian (WDP), di tahun anggaran 2017 memperoleh opini Wajar Tanpa Pengecualian (WTP), tahun anggaran 2018 memperoleh opini Wajar Dengan Pengecualian (WDP), dan di tahun anggaran 2019 LKPD Kabupaten Jember memperoleh opini terendah yakni Tidak Menyatakan Pendapat (Disclaimer). Pemberian opini tersebut dikarenakan terjadi fraud atau penyimpangan penyajian laporan keuangan pemerintah. (Surabaya.bpk.go.id diakses pada 13 Juli 2020). Berdasarkan latar belakang diatas, penelitian ini bertujuan untuk menganalisis faktor-faktor yang berpengaruh terhadap keterandalan pelaporan keuangan Pemerintah Daerah Kabupaten Jember. Faktor tersebut antara lain, pengawasan keuangan, pemanfaatan TI, komitmen organisasi dan kompetensi SDM.

\section{METODE PENELITIAN}

Jenis penelitian ini adalah deskriptif dengan pendekatan kuantitatif. Data dikumpulkan menggunakan hasil dari kuesioner penelitian yang didistribusikan kepada para responden penelitian, dan analisis statistik yang digunakan adalah analisis SEM. Variabel dalam penelitian ini adalah pengawasan keuangan (X1), pemanfaatan TI (X2), komitmen organisasi (X3), kompetensi SDM (X4), dan keterandalan pelaporan keuangan (Y). Teknik pengambilan sampel yang diterapkan dalam penelitian ini adalah metode purposive sampling. Responden/sampel dalam penelitian ini dipilih berdasarkan kriteria informasi yang dibutuhkan, yakni para pegawai yang melaksanakan fungsi pengelolaan keuangan pada SKPD. Di setiap SKPD terdapat 5 orang pegawai pengelola keuangan, jadi jumlah sampel dalam penelitian ini adalah 100 sampel/responden.

Teknik analisis data pada penelitian ini menggunakan Structural Equation Modeling berbasis Partial Least Square (PLS-SEM). Smart PLS atau Smart Partial Least Square adalah apliksi/program statistik yang memiliki peran serupa dengan Lisrel dan AMOS untuk analisis hubungan antar variabel, baik sesama variabel latent maupun dengan indicator (Narimawati, et al. 2020). SEM PLS memiliki 2 analisis yakni Outer Model (uji validitas, dan uji reliabilitas) dan Inner Model (Uji R-square dan uji hipotesis).

\section{HASIL DAN PEMBAHASAN}

Penelitian ini dilakukan pada 100 orang pegawai pengelola keuangan di 20 SKPD di Kabupaten Jember. Peneliti menyebarkan 100 kuesioner ke 100 pegawai di 20 SKPD, masing-masing SKPD menerima 5 kuesioner untuk 5 pegawai di bidang pengelolaan keuangan dan didapatkan hasil sebanyak 80 kuesioner sedangkan 20 kuesioner tidak kembali dikarenakan ada kendala-kendala tertentu dimasing-masing SKPD. Kendala yang paling dominan terjadi adalah karena faktor pandemic Covid-19 sehingga membuat beberapa SKPD sibuk dilapangan dan tak memiliki waktu untuk mengisi kuesioner tersebut. Dari 80 kuesioner yang telah kembali hanya 65 kuesioner yang dapat digunakan, karena pada 15 kuesioner lainnya memiliki kekurangan yakni pengisian kuesioner yang belum seluruhnya terisi atau belum lengkap. Sehingga hasil dari data responden/pegawai SKPD pada kuisioner yang telah terkumpul sebanyak 65 kuesioner. 


\section{Analisis Outer Model}

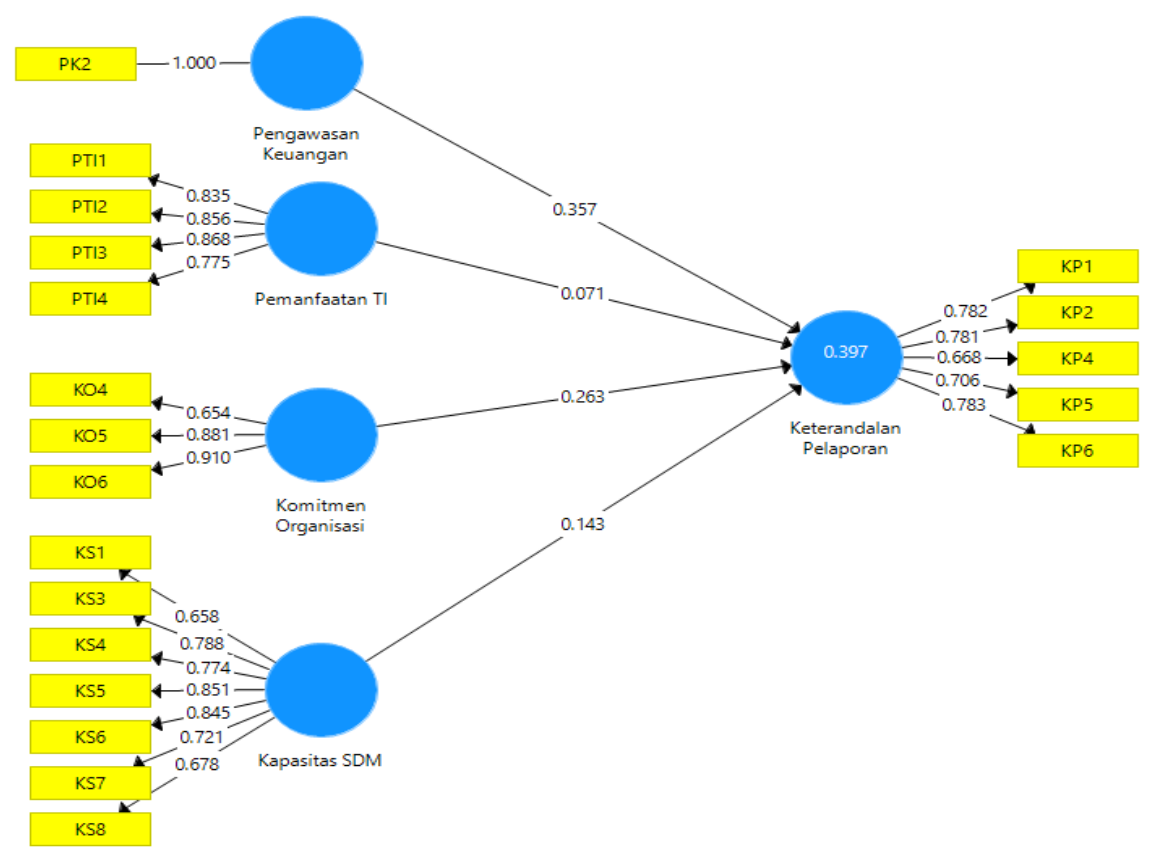

Gambar 1. Model PLS

\section{Uji Validitas}

Berdasarkan hasil pada gambar model outer loading dan cross loading di atas yang memiliki nilai uji validitas lebih besar dari 0,6 dapat dijelaskan bahwa indicatorindikator yang digunakan untuk mengukur masing-masing variabelnya merupakan alat ukur yang tepat untuk mengukur masing-masing variabelnya atau dapat juga dikatakan mampu menjelaskan variabelnya.

\section{Uji Reliabilitas}

Pada tabel Composite Reliability dan Cronbach Alpha di bawah, menunjukan nilai Composite Reliability semua variabel memiliki nilai $>0,7$. Berdasarkan hasil tersebut dapat disimpulkan bahwa semua variabel atau alat ukur yang digunakan memiliki reliabilitas yang baik.

Tabel 1. Nilai Composite Reliability

\begin{tabular}{lc}
\hline \multicolumn{1}{c}{ VARIABEL } & NILAI COMPOSITE RELIABILITY \\
\hline Pengawasan Keuangan (PK) & 1.000 \\
Pemanfaatan TI (PTI) & 0.901 \\
Komitmen Organisasi (KO) & 0.861 \\
Kompetensi SDM (KS) & 0.906 \\
Keterandalan Pelaporan (KP) & 0.862 \\
\hline
\end{tabular}


Tabel 2. Nilai Cronbach Alpha

\begin{tabular}{cc}
\hline VARIABEL & NILAI CRONBACH ALPHA \\
\hline Pengawasan Keuangan (PK) & 1.000 \\
Pemanfaatan TI (PTI) & 0.854 \\
Komitmen Organisasi (KO) & 0.751 \\
Kompetensi SDM (KS) & 0.882 \\
\hline
\end{tabular}

\section{Analisis Inner Model Nilai R-Square}

Tabel 3. Nilai $R$-square

\begin{tabular}{cc} 
& R-square \\
\hline Keterandalan Pelaporan Keuangan $(\mathrm{Y})$ & 0.397 \\
\hline
\end{tabular}

Berdasarkan hasil pada tabel 3 di atas, yakni 0.397 untuk variabel Keterandalan Pelaporan Keuangan (KP) yang dimana hal tersebut berarti bahwa pengawasan keuangan, pemanfaatan TI, komitmen organisasi, dan kompetensi SDM mampu menjelaskan variabel Y sebesar 0.397 atau sama dengan 39,7\%. Sedangkan sisanya $(100 \%-39,7 \%=60,3 \%)$ dipengaruhi oleh variabel lain diluar variabel yang diteliti.

\section{Uji Hipotesis}

Tabel 4. Pengaruh Langsung (Path Coefficient)

\begin{tabular}{|c|c|c|c|c|}
\hline & $\begin{array}{c}\text { Original } \\
\text { Sample (O) }\end{array}$ & $\begin{array}{c}\text { Sample Mean } \\
(\mathbf{M})\end{array}$ & $\begin{array}{c}\text { Standard } \\
\text { Deviation }\end{array}$ & $\begin{array}{c}\boldsymbol{P} \\
\text { values }\end{array}$ \\
\hline $\mathrm{PK} \rightarrow \mathrm{KP}$ & 0.375 & 0.342 & 0.118 & 0.003 \\
\hline $\mathrm{PT} \rightarrow \mathrm{KP}$ & 0.071 & 0.057 & 0.135 & 0.599 \\
\hline $\mathrm{KO} \rightarrow \mathrm{KP}$ & 0.263 & 0.286 & 0.121 & 0.030 \\
\hline $\mathrm{KS} \rightarrow \mathrm{KP}$ & 0.143 & 0.182 & 0.107 & 0.181 \\
\hline
\end{tabular}

\section{Hipotesis 1}

Berdasarkan tabel 4. di atas, menunjukan hasil analisis hubungan dari variabel Pengawasan Keuangan (PK) yang signifikan terhadap variabel Keterandalan Pelaporan Keuangan (KP) dengan nilai P values sebesar $0.003<0.05$. Dengan demikian, hipotesis 1 dalam penelitian ini diterima. Hal tersebut sejalan dengan hasil penelitian oleh Primayana; et al., (2014) di Kabupaten Buleleng, dan Sari (2017) di Kabupaten Solok Selatan, yang membuktikan bahwa pengawasan keuangan memiliki pengaruh terhadap keterandalan keuangan pemerintah. Berdasarkan hasil pengujian hipotesis menunjukkan bahwa pengawasan keuangan memiliki pengaruh positif dan signifikan terhadap keterandalan pelaporan keuangan Pemerintah Kabupaten Jember. para responden yang menyatakan bahwa di instansi tempat mereka berkerja rutin dilakukan pengawasan keuangan secara periodik (triwulan, semester, dan tahunan) baik oleh badan pengawas, inspektorat, maupun pimpinan untuk mendukung kelancaran program yang telah direncanakan dan menciptakan informasi pelaporan keuangan organisasi pemerintah daerah yang jujur, dan andal. Pimpinan organisasi juga selalu memastikan setiap rekomendasi hasil audit BPK segera ditindaklanjuti.

\section{Hipotesis 2}

Berdasarkan hasil analisis menunjukkan hubungan dari variabel Pemanfaatan TI (PTI) yang tidak signifikan terhadap variabel Keterandalan Pelaporan Keuangan (KP) dengan nilai P values sebesar $0.599>0.05$. Dengan demikian, hipotesis 1 dalam penelitian ini ditolak. Hipotesis tersebut tidak mendukung penelitian dari Karmila; et al., (2014), Primayana; et al., (2014), Komarasari, (2016), dan Sari, (2017), (Azlan et al., 2019) yang menyatakan bahwa pemanfaatan TI berpengaruh positif signifikan terhadap keterandalan pelaporan keuangan di masing-masing kabupaten.

Hasil hipotesis dari penelitian ini sejalan dengan penelitian dari Sandanafu; et al., (2018), menunjukkan bahwa pemanfaatan TI tidak berpengaruh terhadap 
keterandalan pelaporan keuangan Pemerintah Maluku. Berdasarkan hasil tersebut dapat disimpulkan bahwa pemanfaatan TI oleh SKPD Kabupaten Jember tidak mempengaruhi keterandalan pelaporan keuangan yang dihasilkan, dikarenakan terdapat masalah yang terkadang terjadi dimana jaringan internet yang melambat, puncaknya dapat terjadi pada saat software digunakan secara bersamaan oleh semua SKPD pada akhir tahun anggaran, hal dapat tersebut terjadi karena jaringan yang digunakan oleh semua SKPD, atau karena gangguan sistem, sehingga dapat memperlambat proses pembuatan laporan keuangan di SKPD tersebut.

\section{Hipotesis 3}

Berdasarkan hasil analisis menunjukkan hubungan dari variabel Komitmen Organisasi (KO) yang signifikan terhadap variabel Keterandalan Pelaporan Keuangan (KP) dengan nilai P values sebesar $0.030<0.05$. Dengan demikian, hipotesis 1 dalam penelitian ini diterima. Hasil hipotesis tersebut sejalan dengan penelitian dari Anggreini Permata Sari (2017) di Solok Selatan. Seorang pegawai yang berkomitmen tinggi untuk memberikan kemampuan terbaiknya kepada lembaga akan selalu berusaha untuk meningkatkan kinerjanya. Jika kinerja seorang pegawai keuangan baik maka hal tersebut dapat mempengaruhi pada output yang dihasilkan yakni laporan keuangan pemerintah daerah yang andal.

\section{Hipotesis 4}

Berdasarkan hasil analisis menunjukkan hubungan dari variabel Kompetensi SDM (KS) yang signifikan terhadap variabel Keterandalan Pelaporan Keuangan (KP) dengan nilai $\mathrm{P}$ values sebesar $0.181>0.05$. Dengan demikian, hipotesis 1 dalam penelitian ini ditolak. Berbeda dengan hasil penelitian Primayana; et al., (2014) dan Sari, (2017), yang telah melakukan penelitian tersebut di daerah Buleleng dan Solok Selatan, menyatakan bahwa kapasitas SDM mempengaruhi keterandalan pelaporan keuangan, hasil hipotesis dalam penelitian ini mendukung penelitian dari Karmila; et al., (2014), yang juga memiliki hasil penelitian bahwa kapasitas SDM tidak berpengaruh terhadap keterandalan pelaporan.

Hasil penelitian menunjukkan karena sebagian besar pegawai berlatar belakang pendidikan non akuntansi. Meski SKPD telah menggunakan sistem/program akuntansi yang baik akan tetapi SDM kurang mendukung sesuai bidangnya, hal tersebut juga dapat menjadi hambatan dalam proses akuntansi dan mempengaruhi informasi yang dihasilkan. Sehingga diperlukan adanya pelatihan yang maksimal sesuai bidang/posisi perkerjaan untuk meningkatkan kompetensi SDM yang ada agar tercipta output yang baik dan handal.

\section{SIMPULAN}

Berdasarkan hasil analisis dan pengujian hipotesis dari penelitian ini, berikut beberapa kesimpulan yang bisa diperoleh yaitu Variabel Pengawasan Keuangan (PK) berpengaruh positif signifikan terhadap variabel Keterandalan Pelaporan Keuangan (KP) dengan nilai P values sebesar $0.003<0.05$, Karena pada SKPD Kabupaten Jember telah rutin dilakukan pengawasan keuangan baik oleh badan pengawas, inspektorat, maupun pimpinan untuk mendukung kelancaran program yang telah direncanakan.

Variabel Pemanfaatan TI (PTI) tidak berpengaruh signifikan terhadap variabel Keterandalan Pelaporan Keuangan (KP) dengan nilai P values sebesar 0.599 > 0.05, Karena terdapat masalah yang terkadang terjadi dimana jaringan internet yang melambat, puncaknya terjadi pada saat software digunakan secara bersamaan oleh semua SKPD pada akhir tahun anggaran.

Variabel Komitmen Organisasi (KO) berpengaruh positif signifikan terhadap variabel Keterandalan Pelaporan Keuangan (KP) dengan nilai P values sebesar 0.030 $<0.05$, Seorang pegawai keuangan yang memiliki komitmen tinggi terhadap 
organisasinya dapat berdampak pada output yang dihasilkan, yakni laporan keuangan pemerintah daerah yang andal.

Variabel Kompetensi SDM (KS) tidak berpengaruh signifikan terhadap variabel Keterandalan Pelaporan Keuangan (KP) dengan nilai P values sebesar $0.181>0.05$, Karena dari 65 responden pegawai yang memiliki fungsi sebagai pengelola keuangan pada SKPD dalam penelitian ini, beberapa diantaranya memiliki latar belakang pendidikan non-akuntansi ataupun ekonomi.

Keterbatasan dalam penelitian ini adalah objek penelitiannya yang terbatas. Saran bagi para peneliti selanjutnya diharapkan mampu memperluas objek penelitian sehingga hasil yang diperoleh akan lebih maksimal.

\section{DAFTAR RUJUKAN}

Azlan, M., Herwanti, T., \& Pituringsih, E. (2019). Pengaruh Kualitas Sumber Daya Manusia, Pemanfaatan Teknologi Informasi, Pengendalian Intern Akuntansi, Dan Pengawasan Keuangan Daerahterhadap Keandalan Laporan Keuangan Daerah Pada Skpd Pemerintah Kabupaten Lombok Timur. Jurnal Akuntansi Aktual, 3(2), 188-198.

Karmila; et al. (2014). Pengaruh Kapasitas Sumber Daya Manusia, Pemanfaatan Teknologi Informasi, Dan Pengendalian Intern Terhadap Keterandalan Pelaporan Keuangan Pemerintah Daerah (Studi Pada Pemerintah Provinsi Riau). Jurnal Sorot, Vol. 9(No. 1), 1-18.

Komarasari, W. (2016). Pengaruh Kapasitas Sumber Daya Manusia, Pemanfaatan Teknologi Informasi dan Pengendalian Intern Akuntansi Terhadap Keterandalan Pelaporan Keuangan Daerah (Pada SKPD Kabupaten Bantul Bagian Akuntansi dan Keuangan). Jurnal Telaah \& Riset Akuntansi, 2(2), 65-66. https://doi.org/10.1021/om050941q

Narimawati, U. ; et al. (2020). Ragam Analisis dalam Metode Penelitian: untuk Penulisan Skripsi, Tesis, \& Disertasi.

Primayana, K. H., . SE Ak. M., A. T. A., \& . S.E. Ak., N. A. S. D. (2014). Pengaruh Kapasitas Sumber Daya Manusia, Pengendalian Intern Akuntansi, Pemanfaatan Teknologi Informasi, Dan Pengawasan Keuangan Daerah Terhadap Keterandalan Pelaporan Keuangan Pemerintah Daerah (Studi Pada Pemerintah Daerah Kabupaten Buleleng). 1(1).

Sandanafu, S. P., \& Situmeang, M. F. (2018). Pengaruh Kapasitas SDM, Kompitmen Organisasi, Pemanfaatan Teknologi Informasi Dan Pengendalian Intern Akuntansi Terhadap Nilai Informasi Pelaporan Keuangan Pemerintah Daerah. Jurnal Maneksi, 7(2), 100-109.

Sari, A. P. (2017). Pengaruh Sumber Daya Manusia, Komitmen Organisasi, Pemanfaatan Teknologi Informasi, Pengawasan Keuangan Daerah Dan Pengendalian Intern Akuntansi Terhadap Keandalan Pelaporan Keuangan Pemerintah Daerah Kabupaten Solok Selatan. JOM Fekon, Vol.4 No.1, 1-15.

Susanto, A. (2017). Sistem Informasi Akuntansi : pemahaman konsep secara terpadu. In Lingga jaya (Vol. 53, Issue 9). 